\title{
Construcción de un vector de expresión derivado de virus adenoasociados para corregir in vitro el defecto genético de la enfermedad de Morquio A
}

\author{
Mónica A. Gutiérrez',2,t, Felipe García-Vallejo ${ }^{3}$, Shunji Tomatsu², Flavio Cerón³, \\ Carlos J. Alméciga-Díaz', Martha C. Domínguez³ ${ }^{1}$, Luis A. Barrera ${ }^{1}$ \\ ${ }^{1}$ Instituto de Errores Innatos del Metabolismo, Pontificia Universidad Javeriana, Bogotá, D.C., Colombia \\ 2 Department of Pediatrics, Saint Louis University, Saint Louis, MO, United States \\ ${ }^{3}$ Laboratorio de Biología Molecular, Facultad de Salud, Universidad del Valle, Cali, Colombia \\ ${ }^{t}$ R. I. P.
}

Introducción. La mucopolisacaridosis IV A (Morquio A) es una enfermedad de depósito lisosómico causada por la deficiencia en la actividad de la enzima N-acetil-galactosamina-6sulfato-sulfatasa que produce la acumulación intralisosómica de queratán y condroitín-6-sulfato. Hasta el momento, su manejo es paliativo, por lo que las investigaciones se han enfocado en establecer una terapia que pueda aplicarse tempranamente y garantice la expresión estable de la enzima. En este sentido, la terapia génica se presenta como una de las potenciales alternativas terapéuticas para corregir el defecto genético en la mucopolisacaridosis IV A.

Objetivo. Construir vectores de expresión derivados de virus adenoasociados para corregir in vitro la deficiencia enzimática en la mucopolisacaridosis IV A.

Materiales y métodos. Se produjeron vectores derivados de virus adenoasociados que portaban el gen humano de la enzima $\mathrm{N}$-acetil-galactosamina-6-sulfato-sulfatasa dirigido por el promotor temprano del citomegalovirus humano, empleando un sistema libre de adenovirus. Se transfectaron células HEK293 y fibroblastos humanos Morquio A con los virus recombinantes, y se determinó la actividad enzimática en el lisado celular a las 24 y 48 horas después de la transfección.

Resultados. Se obtuvieron virus adenoasociados recombinantes, libres de adenovirus, con títulos hasta de $2,08 \times 10^{10}$ cápsides/ml. Tanto en células HEK293 como en fibroblastos Morquio A transfectados, se obtuvieron actividades enzimáticas hasta de 3,05 nmoles/mg por hora, 48 horas después de la transfección.

Conclusión. Los virus recombinantes producidos expresaron in vitro la enzima GALNS en las células transfectadas. Estos resultados constituyen el paso inicial para el desarrollo de una terapia génica para la enfermedad de Morquio A empleando vectores derivados de virus adenoasociados.

Palabras clave: mucopolisacaridosis IV A/genética, dependovirus, terapia de gen, técnicas de transferencia de gen, cultivo de virus, técnicas de cultivo.

Construction of an adenoassociated, viral derived, expression vector to correct the genetic defect in Morquio A disease

Introduction. Mucopolysaccharidosis IVA (Morquio A) is caused by a deficiency of $\mathrm{N}$ acetylgalactosamine-6-sulphate-sulphatase, a lysosomal enzyme required for the stepwise degradation of keratan-sulfate and chondroitin-6-sulfate. A deficiency in this enzyme results in an accumulation of glycosaminoglycans in several tissues. Currently, no effective therapies exist and only supportive measures are used to treat some manifestations of the disease. An ideal therapy is one that can be administrated early in life, has low mortality, and leads to longterm expression of the enzyme. Gene therapy emerges as a potential alternative to correct the genetic defect in MPS IVA.

Objective. Adenoassociated virus-derived expression vectors (AAV) were constructed to correct in vitro the enzyme deficiency in mucopolysaccharidosis IVA. 


\begin{abstract}
Materials and methods. Adenoasociated virus-derived vectors containing the human GALNS gene and driven by the citomegalivirus immedited-early promoter were constructed using a free-adenoviral protocol. HEK293 cells and human skin Morquio A fibroblasts were transfected with the recombinat vectors. Enzyme activity was measured in cells 24 and 48 hours posttransfection.

Results. Free-adenovirus recombinant AAV vectors were obtained with titres up to $2.08 \times 10^{10}$ capsids/mL. HEK293 cells and Morquio A fibroblasts transfected with vectors showed GALNS activity up to $3.05 \mathrm{nmoles} / \mathrm{mg} / \mathrm{h} 48$ hours post-transfection.

Conclusion. The AAV mediated the in vitro expression of GALNS enzyme in the transfected cells. These results are the first step towards a gene therapy alternative to Morquio A disease using adenoassociated virus-derived vectors.
\end{abstract}

Key words: Mucopolysaccharidosis IV/genetics, dependovirus, gene therapy, gene transfer techniques, virus cultivation, culture techniques.

La mucopolisacaridosis IV A (MPS IV A, OMIM 253000) es un error innato del metabolismo de depósito lisosómico, causado por la deficiencia de la enzima $\mathrm{N}$-acetil-galactosamina-6-sulfato sulfatasa (GALNS, E.C.3.1.6.4), involucrada en la degradación de queratán sulfato y condroitín-6sulfato, con la consecuente acumulación intralisosómica de estos glucosaminoglicanos (GAG) y su aumento en la excreción urinaria (1).

El fenotipo de la enfermedad varía desde una forma grave con displasia esquelética importante, estatura corta, anormalidades articulares, facies toscas, hipoplasia de la odontoides, cuello corto, opacidad corneal del estroma y compromiso cardiaco, hasta una forma media con manifestaciones menos acentuadas (2,3). La expectativa de vida para estos individuos oscila entre los 20 y 30 años, aunque algunos pacientes con fenotipos medios pueden alcanzar hasta la sexta o séptima décadas de vida. No existe evidencia de alteraciones del sistema nervioso central $(2,3)$.

En la actualidad, no se dispone de una terapia efectiva y el manejo se realiza exclusivamente de forma paliativa, aunque los ensayos clínicos de la terapia de reemplazo enzimático están próximos a iniciarse $(3,4)$. Es necesario, entonces, el desarrollo de una estrategia que permita mantener niveles enzimáticos durante periodos

\footnotetext{
Correspondencia:

Luis A. Barrera, Instituto de Errores Innatos del Metabolismo, Pontificia Universidad Javeriana, Carrera 7 № 43-82, laboratorio 305A, edificio 53, Bogotá, D.C., Colombia abarrera@javeriana.edu.co

Recibido: 03/12/07; aceptado:27/06/08
}

prolongados y dentro de una ventana terapéutica. La terapia génica emerge como una de las principales alternativas para la corrección del defecto genético, de manera semipermanente 0 , incluso, permanente, para ésta y otras enfermedades lisosómicas (5).

EI ADNc de GALNS ha sido clonado y su secuencia codifica para una proteína de 522 aminoácidos, incluso un péptido señal de 26 aminoácidos (6). Hasta la fecha, se han identificado más de 150 mutaciones, $74 \%$ de ellas debidas a sustituciones de nucleótidos de tipo sin sentido o de sentido errado $(3,7)$. Para la población colombiana se han identificado las mutaciones pG301C, pS162F y pF69B, las cuales no han sido reportadas en otras poblaciones (8). Además, el hallazgo de cuatro esculturas de la época precolombina, con claros rasgos de individuos afectados con mucopolisacaridosis IV A, apuntan a la existencia de esta enfermedad en nuestros antepasados (9).

Durante los últimos años, los vectores derivados de virus adenoasociados han llamado la atención de la comunidad científica, por no ser patógenos para los humanos y por su capacidad de infectar células en división y quiescentes (10-14). Poseen un diámetro de 20 a $25 \mathrm{~nm}$ y están compuestos de una mezcla de proteínas de ensamblaje que encapsidan un genoma de ADN de cadena sencilla de 4,7 kb, aproximadamente, flanqueado por dos repeticiones terminales invertidas (inverted terminal repeat, ITR) de 145 bases, que contienen el origen de replicación y son necesarias para el empaquetamiento viral (13). 
Para su replicación y producción, se requiere de la coinfección con un virus ayudador de tipo adenovirus o herpes simple $(15,16)$. En ausencia del virus ayudador, el genoma de los virus silvestres asociados al ADN se integra en el genoma humano, específicamente en la posición 19q13.4, mientras que los vectores recombinantes son encontrados principalmente de manera episómica $(12,17)$.

Los vectores de virus adenoasociados se han empleado en ensayos preclínicos in vivo de enfermedades lisosómicas, como las de Gaucher, Fabry, Pompe, Hurler, Sanfillippo B, MaroteauxLamy y Sly $(5,18)$, en las cuales se han alcanzado valores terapéuticos de actividad enzimática, principalmente en hígado, corazón, pulmón y suero, tras la administración intravenosa del vector (19-22) o en músculo, cerebro y ojo, tras la inyección directa (23-25). En todos los casos, los acúmulos de GAG se disminuyeron en una gran proporción y la arquitectura del tejido se restauró, lo cual se manifestó en una corrección de las características fenotípicas de las enfermedades $(18,26)$.

En este estudio se construyó el vector de expresión episómica pIRESneo2-GALNS, dirigido por el promotor temprano del citomegalovirus humano (CMVIE). Este casete de expresión se utilizó para la generación del plásmido pAAVGALNS que permitió la producción de los vectores de virus adenoasociados recombinantes ( $\mathrm{rAAV}$ GALNS), mediante un sistema libre de adenovirus. Este es el primer estudio reportado en que se utilizan virus adenoasociados para corregir in vitro la deficiencia de GALNS.

\section{Materiales y métodos \\ Construcción del casete de expresión pIRESne02-GALNS}

EI ADNc de GALNS se obtuvo por restricción del plásmido pCXN-GALNS (27) con EcoRI (Gibco). El fragmento de 1,7 kb se insertó en el sitio EcoRI del vector pIRESneo2 (CLONTECH), el cual posee el promotor temprano del citomegalovirus, un intrón sintético, la secuencia del sitio de entrada al ribosoma del virus de la encefalomiocarditis seguida por el gen de neomicina fosfotransferasa y la señal de poliadenilación de la hormona de crecimiento bovina (figura 1 ).

\section{Construcción del vector recombinante pAAV- GALNS}

El fragmento Xhol-Nrul $(4,5 \mathrm{~kb})$ del casete de expresión pIRESneo2-GALNS, se insertó en el plásmido pSub201 (14), previa restricción de éste con Xbal (figura 2). pSub201 contiene los ITR del serotipo AAV2 flanqueando los genes Rep y Cap de este mismo serotipo. Todos los extremos cohesivos se rellenaron utilizando el fragmento Klenow de la ADN polimerasa I de Escherichia coli (New England Biolabs).

\section{Confirmación de los clones pIRESneo2- GALNS y $p A A V$-GALNS}

La evaluación de la inserción y dirección del ADNc de GALNS se realizó inicialmente por análisis de restricción con EcoRI, Bglll y BamHI (Promega) $y$, posteriormente utilizando los cebadores $H G$ : 5'-ATGGCGGCGGTTGTCGCGGCGACGAGGT GGTGG y TOMF33R:5'-GGGAACTCTCCCC TGGG TCC, los cuales se encuentran ubicados en el extremo 5' y $3^{\prime}$ del ADNc de GALNS, respectivamente. El producto del PCR de 1,3 kb fue digerido con BamHI (Promega). La integridad del ADNc de GALNS fue confirmada mediante secuenciación (Retrogen Inc., San Diego, CA, USA) usando los cebadores TOMF19 5'C G G A C G C T C G C T A G G T C G G C T C G CTGG,TOMF21 5'-CGGCAAG TGGCATCTGGG TCACAGG,TOMF22 5'-TCTATGCCTCCAAACC CTTCTTGGGCA,TOMF23 5'-ACAGGGCCATTGA TGGCCTCAACCTCCT y TOMF34R 5'GCTTCGTGTGGTCTTCCAGATTGTGAGTTG, los cuales permiten la obtención de la secuencia completa del ADNc de GALNS. El producto de la secuencia fue alineado con la secuencia disponible en GenBank (número de acceso NM_000512) empleando la herramienta BI2seq (http://blast.ncbi.nlm.nih.gov/blast.cgi).

La selección de los clones pAAV-GALNS se llevó a cabo mediante análisis de restricción con Nael y Ndel. La integridad del ADNc de GALNS en esta construcción, se realizó por PCR y obtención de la secuencia como se describió previamente para pIRESneo2-GALNS. Además, se secuenciaron 
parcialmente las regiones cercanas a los sitios de ligación (Retrogen Inc., San Diego, CA, USA), para confirmar la direccionalidad del inserto e integridad de los ITR, utilizando los cebadores CMVR: 5'-ACGTCAATGGAAAGTCCCTA, GHPAF: 5'-AGCCTCGACTGTGCCTTCTA, 3'ITRF: 5'-CGCCTTTGAGTGAGCTGATA y 5'ITRR:5'-CGCTCATGGAAATACCTACA (figura 2).

\section{Producción de partículas virales de virus adenoasociados recombinantes}

Se cotransfectaron células HEK293 (ATCC CRL1573), una línea celular permanente de riñón embrionario humano transformada con ADN del adenovirus tipo 5 humano, con: pAAV-GALNS o pSub201 (control), pXX2 (plásmido de empaquetamiento para el serotipo AAV2) y pXX6 (plásmido ayudador), en una relación 5:5:15 $\mu \mathrm{g}$ de ADN, respectivamente, lo que corresponde a una relación molar 1:1:1 (14).

Las células se sembraron 48 horas antes de la transfección en placas de $10 \mathrm{~cm}$ de diámetro a una densidad de $1 \times 10^{6}$ con Eagle's MEM (GIBCO), con suplemento de glutamina (GIBCO) $2 \mathrm{mM}$, aminoácidos no esenciales (GIBCO) 0,1 $\mathrm{mM}, \mathrm{HEPES}$ (GIBCO), suero fetal bovino (GIBCO) al $10 \%$ y libre de antibióticos.

La cotransfección de las células, en el $70 \%$ al $80 \%$ de confluencia (aproximadamente, $2,5 \times 10^{6}$ células), se realizó con Lipofectamine 2000 (Invitrogen), siguiendo las instrucciones del fabricante. Pasadas 48 horas, las células y el medio de cultivo fueron recolectados empleando un rastrillo para levantar las células. La suspensión celular se sometió a 3 ciclos de congelación y descongelación y se clarificó por centrifugación a $3.000 \mathrm{~g}$ por 10 minutos a temperatura ambiente. El sobrenadante, solución viral primaria $(\sim 10 \mathrm{ml})$, fue almacenado a $-80^{\circ} \mathrm{C}$.

\section{Titulación de partículas virales}

El título viral fue establecido mediante ELISA empleando el estuche AAV titration ELISA: Enzyme immunoassay for the quantitative determination of AAV particles in cell culture supernatants and purified virus preparations (Progen-Biotechnik). El número de partículas virales se determinó comparando la absorbancia obtenida por las muestras contra una curva de calibración realizada con una suspensión viral suministrada en el estuche. Este método permite la captura de partículas virales completas, pero no de las proteínas aisladas de la cápside (28).

\section{Transfección de las células con los rAAV- GALNS}

Se transfectaron células HEK293 y fibroblastos de piel de un paciente con MPS IV A, con los vectores rAAV-GALNS. Las células se sembraron en placas de seis pozos, tres días antes de la infección, a una densidad de $1,5 \times 10^{5}$ células/ pozo, usando el medio de crecimiento MEM descrito anteriormente sin antibióticos y se incubaron a $37^{\circ} \mathrm{C}$ en atmósfera microaerofílica de $5 \%$ de $\mathrm{CO}_{2}$, hasta alcanzar $70 \%$ de confluencia (aproximadamente, $5 \times 10^{5}$ células).

Sin remover el medio, a cada cultivo se le agregó $1 \mathrm{ml}$ de medio permisible (MEM sin antibióticos, con suplemento de hidroxiurea $240 \mathrm{mM}$ (Sigma) y butirato de sodio $6 \mathrm{mM}$ (Sigma)). Los cultivos se incubaron por 5 horas a $37^{\circ} \mathrm{C}$ en $5 \%$ de $\mathrm{CO}_{2}$. Las células se lavaron con MEM sin antibióticos y suero fetal bovino al $2 \%$ (29). A cada cultivo se le adicionaron $1 \times 10^{10}$ cápsides de los virus rAAVGALNS/4, rAAV-GALNS/24 y AAV-2 y se incubaron por 2 horas, con rotación suave cada 30 minutos. Finalmente, se adicionaron $0,5 \mathrm{ml}$ de medio de MEM con suplemento de suero fetal bovino al $18 \%$, continuando el cultivo por 24 y 48 horas.

\section{Actividad enzimática GALNS}

Las células HEK293 y lo fibroblastos MPS IV A transfectados y no transfectados se sometieron a ciclos de congelación y descongelación, 24 y 48 horas después de la transfección. La actividad enzimática se determinó en los lisados celulares, siguiendo el método de van Diggelen et al. (30) con modificaciones. El método emplea el sustrato fluorogénico 4-metilumbelliferil- $\beta$-D-galactopiranósido-6-sulfato de sodio, el cual permite la determinación específica de la actividad GALNS y es empleado para el diagnóstico de pacientes con la enfermedad de Morquio A (30). La actividad enzimática se expresó en nanomoles de sustrato catalizado en una hora por miligramos de proteína 

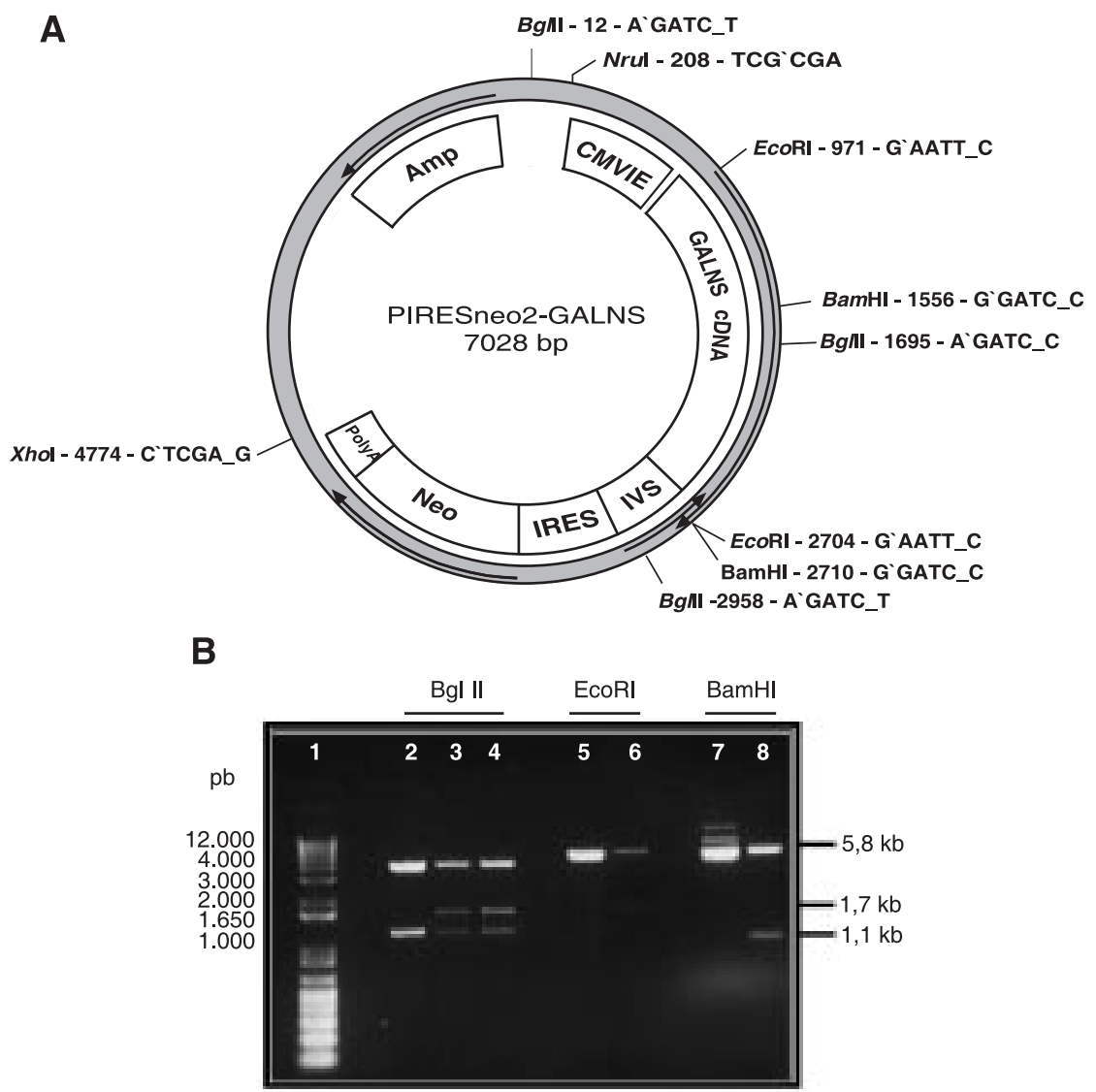

Figura 1. Construcción del plásmido de expresión episómica pIRESneo2-GALNS. A) Esquema del plásmido pIRESneo $_{2}^{-}$ GALNS. CMV/IE: promotor temprano del citomegalovirus humano (CMV); IVS: intrón sintético; IRES: sitio interno atenuado de entrada al ribosoma (IRES) del virus del encéfalo miocarditis; Neo: secuencia codificante de neomicina fosfotransferasa; PolyA: señal de poli-A de la hormona bovina de crecimiento, y Amp: gen de la B-lactamasa. B) Selección de clones recombinantes correctos por restricción con EcoRI, Bglll y BamHI. Carril 1: Marcador de peso molecular $1 \mathrm{~kb}$ más ADN (GIBCO); carril 2: pIRESneo2 digerido con Bgl II; carriles 3 y 4: clones de pIRESneo2-GALNS digeridos con Bgl II; carril 5: pIRESneo2 digerido con EcoRI; carril 6: El pIRESneo2-GALNS digerido con EcoRI; carril 7: pIRESneo2 con BamHI; carril 8: pIRESneo2-GALNS digerido con BamHI.

en la muestra (nmol/mg por hora). La actividad en fibroblastos transfectados fue comparada con la obtenida en fibroblastos de piel no afectados (normales). La proteína fue determinada por el método de Bradford (Pierce, Rockford, IL).

\section{Resultados}

Generación de los plásmidos pIRESneo2GALNS y PAAV-GALNS

Inicialmente, se construyó el plásmido pIRESneo2GALNS (7028 pb), el cual contiene los elementos necesarios para garantizar la transcripción y transducción estable del ADNc en las células de interés (figura 1a). Se obtuvo un único clon con el ADNc orientado en la dirección correcta. Tras restricción con EcoRI, se observaron dos bandas, una de 5,3 kb correspondiente al pIRESneo2 y otra de 1,7 kb correspondiente al ADNc de la GALNS (figura 1b). Con la enzima Bglll, pIRESneo2-GALNS con el inserto en la orientación correcta, debe generar tres fragmentos de 4.088, 1.637 y $1.275 \mathrm{pb}$, mientras que BamHI debe producir dos fragmentos de 5.831 y $1.169 \mathrm{pb}$. Los carriles 3, 4, 6 y 8 muestran el análisis de restricción del clon pIRESneo2-GALNS con el ADNc insertado en la dirección correcta (figura 

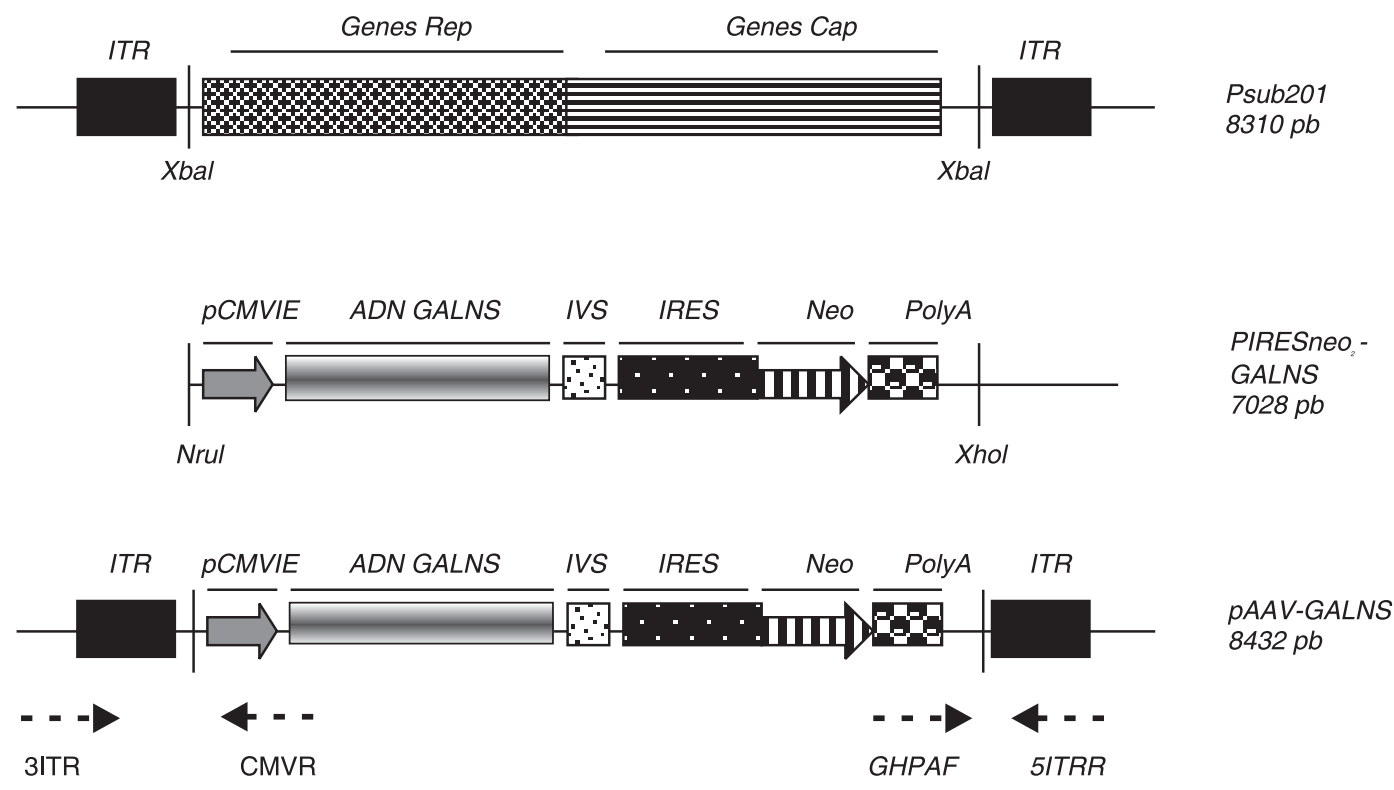

Figura 2. Esquema de construcción del plásmido pAAV-GALNS. El pIRESneo2-GALNS es el casete de expresión usado para producir los virus asociados al ADN (AAV) recombinantes. El pAAV-GALNS se construyó a partir del psub201 reemplazando las secuencias Rep y Cap por el casete de expresión del pIRESneo2-GALNS; se muestran los sitios de restricción para Xbal. Nótese que la restricción permite mantener intactos los ITR. Las flechas punteadas señalan las regiones de reconocimiento de los cebadores y la dirección en la que se realiza la amplificación para la obtención de la secuencia.

1b). La confirmación se realizó por PCR, y se evidenció la banda de $1,3 \mathrm{~kb}$, la cual, al ser digerida con BamHI, produjo dos fragmentos de 876 y 481 pb (figura 3). La secuenciación indicó un 100\% de homología con la secuencia reportada en el GenBank.

El plásmido pAAV-GALNS fue construido reemplazando los genes Rep y Cap del plásmido pSUB201 por el casete de expresión pIRESneo2GALNS de 4533 pb (figura 2). De esta manera, el casete de expresión se encontraba flanqueado por los ITR, que son las únicas secuencias que deben estar en cis, con respecto al transgen, para la producción de las partículas virales y la posterior expresión del gen de interés.

Del total de clones obtenidos con la longitud esperada de 8,4 kb tan sólo 20 portaban el ADNc de GALNS, que se evidenció tras digestión con EcoRI (figura 4A). La confirmación del sentido de inserción del casete se realizó inicialmente por análisis de restricción con Ndel y Nael, en donde sólo los clones pAAV-GALNS/4, pAAV-GALNS/
24 y pAAV-GALNS/39 presentaban los fragmentos esperados de 461, 2.695 y 5.307 pb con Ndel (figura 4B carriles 2 y 5 ) y cuatro de $733,1.186$, 2.059 y $4.485 \mathrm{pb}$ con Nael (figura 4C carriles 3 y 10). El análisis por PCR de los clones 4, 24 y 39 (figura 3) y los resultados de secuenciación (no se muestra el dato) del ADNc de GALNS, arrojaron los mismos resultados que para pIRESneo2-GALNS.

Para la replicación y el empaquetamiento de los virus adenoasociados, es necesario que los ITR se encuentren intactos y ubicados en cis con respecto al transgen, por lo cual los plásmidos pAAV-GALNS se secuenciaron parcialmente para analizar las regiones cercanas a los sitios de ligación. Se demostró un 100\% de homología entre las secuencias obtenidas y las reportadas (12), lo que confirma la integridad de los ITR.

\section{Producción de partículas virales}

Con los tres clones pAAV-GALNS obtenidos, se realizó el procedimiento para la producción de partículas virales recombinantes, utilizando como 


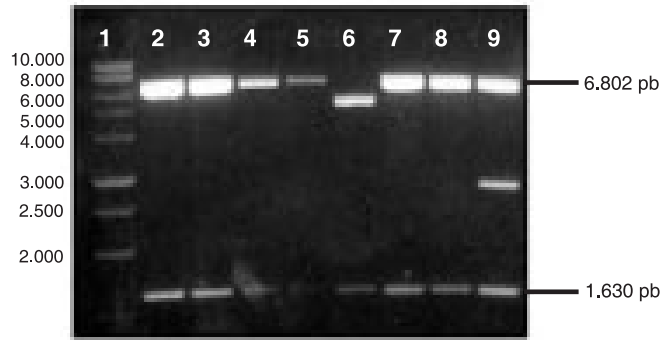

B

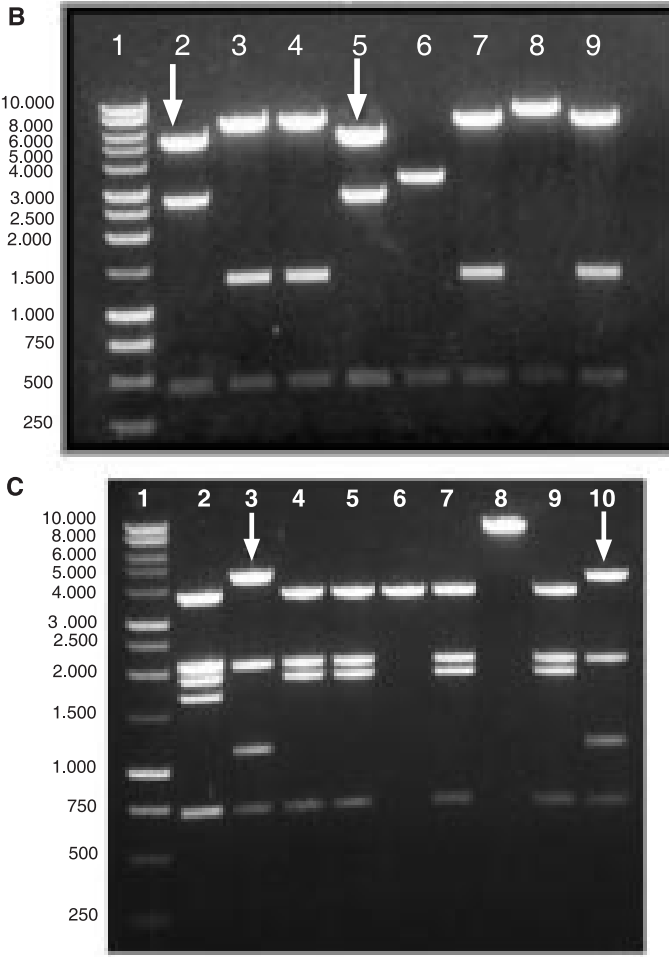

Figura 3. PCR del ADN del plásmido pIRESneo2-GALNS y pAAV-GALNS y restricción con BamHI de los productos de PCR: A) Productos de PCR del pIRESneo2GALNS y pAAV-GALNS. La amplificación de un fragmento de $1.300 \mathrm{pb}$ confirma que el plásmido contiene el ADNc de la GALNS. 1: marcador de peso molecular 1 kb ADN (Promega); 2: control de PCR psub201; 3: pAAVGALNS/4; 4: pAAV-GALNS/24; 5: pAAV-GALNS/39; 6 : pIRESneo2-GALNS; 7: pCXN-GALNS. B) Cuando se visualizaron los productos del PCR, el control del PCR con psub201 mostró amplificación de una banda de longitud similar a la esperada. Los productos de amplificación se digirieron con BamHI, el fragmento del ADNc de la GALNS amplificado tiene un sitio de restricción para esa enzima y produce bandas de 876 y $481 \mathrm{pb}$. 1: marcador de peso molecular de 100 pb (Promega); 2: control psub201; 3: pAAV-GALNS/4; 4: pAAV-GALNS/ 24; 5: pAAV-GALNS/39; 6: pIRESneo2-GALNS; 7: pCXNGALNS.

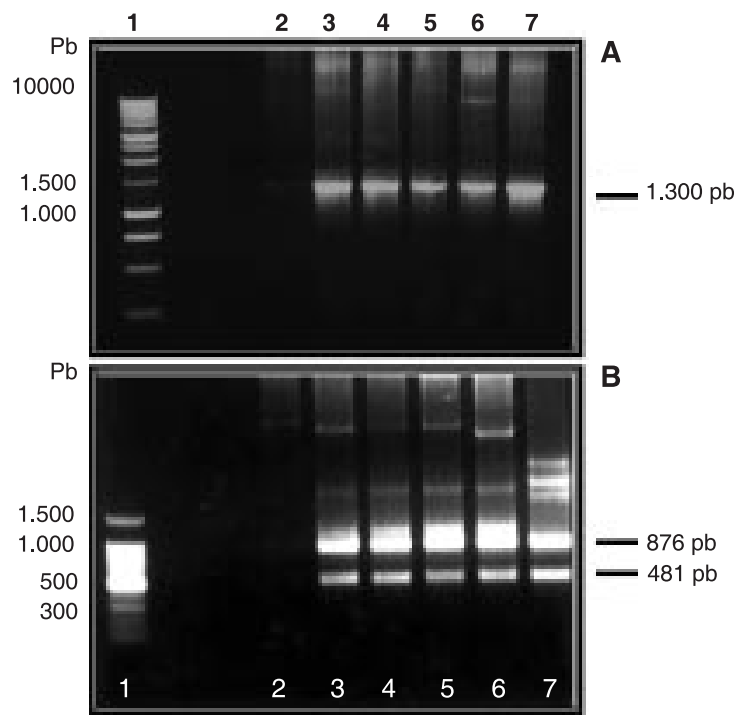

Figura 4. Construcción del plásmido pAAV-GALNS. A) Selección de los plásmidos pAAV-GALNS recombinantes mediante restricción con EcoRI: carril 1, marcador de peso molecular $1 \mathrm{~kb}$ ADN (Promega); carriles 2-5, 7 y 8 restricciones clones positivos para pAAV-GALNS con EcoRI; carriles 6 y 9 , clones negativos para pAAV-GALNS. Los carriles 5,7 y 8 corresponden a los clones pAAV-GALNS/4, pAAV-GALNS/24 y pAAV-GALNS/39, respectivamente. B) Análisis de restricción de clones pAAV-GALNS con Ndel: carril 1: marcador de peso molecular $1 \mathrm{~kb}$ ADN (Promega); carriles 2 y 5: pAAV-GALNS 39 y pAAV-GALNS 24 , respectivamente, digeridos con Ndel; se pueden observar las tres bandas correspondientes a los tamaños esperados para el inserto orientado en sentido; carriles 3, 4, 6 a 9, clones negativos para pAAV-GALNS. C) Análisis de restricción del pAAV-GALNS con Nael: carril 1, marcador de peso molecular $1 \mathrm{~kb}$ ADN (promega), carriles 3 y 10 pAAVGALNS 4 y pAAV-GALNS 39 digeridos con Nael, mostraron el patrón esperado. En los carriles restantes se muestra la separación electroforética de clones negativos.

control el plásmido psub201. Las partículas virales se obtuvieron 48 horas después de la cotransfección, con el objetivo de lograr el mayor número de partículas virales (14). Los títulos obtenidos en el control con psub201 fueron de $4,7 \times 10^{11}$ cápsides $/ \mathrm{ml}$, más altos que los reportados previamente $\left(<1,1 \times 10^{10} \mathrm{cap} / \mathrm{ml}\right)(14)$. Con losvirus asociados al ADN recombinates $\mathrm{rAAV}-\mathrm{GALNS} / 4$, rAAV-GALNS/24 y rAAV-GALNS/39, los títulos virales fueron $2,08 \times 10^{10}, 6,45 \times 10^{9}$ y $3,98 \times 10^{9}$ cápsides $/ \mathrm{ml}$, respectivamente. Debido a que los los vectores rAAV-GALNS/4 y rAAV-GALNS/24 presentaron los mayores títulos virales, fueron seleccionados para el ensayo de transfección. 


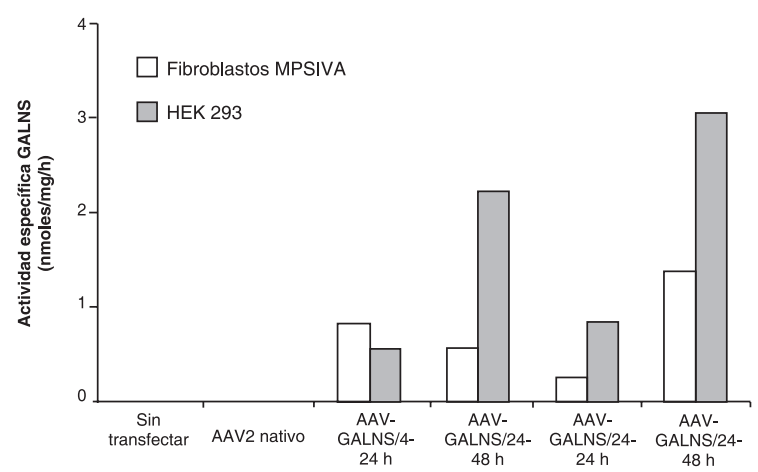

Figura 5. Expresión in vitro de los vectores rAAV-GALNS en fibroblastos MPS IVA y células HEK293. Actividad enzimática de GALNS en el lisado celular de fibroblastos MPS IVA y células HEK293 transfectadas con AAV2 nativo, rAAV-GALNS/4, rAAV-GALNS/24, a las 24 y 48 horas después de la transfección.

\section{Transfección de células HEK 293 y fibroblastos MPS IVA usando los vectores rAAV-GALNS}

Se transfectaron células HEK 293 y fibroblastos MPS IV A con $1 \times 10^{10}$ partículas de rAAV-GALNS/ 4, rAAV-GALNS/24 y AAV2. Cada transfección fue realizada de manera independiente en un único experimento; sin embargo, debido a que los clones pAAV-GALNS empleados para la producción de los virus recombinantes contienen la misma secuencia, cada ensayo de transfección, con rAAV-GALNS/ 4 y rAAV-GALNS/24, fue considerado como una réplica. La expresión de una enzima funcionalmente activa se evidenció con el incremento en la actividad enzimática en el lisado celular (figura 5).

En las células HEK 293 y los fibroblastos MPS IV A sin transfectar o transfectados con el virus AAV2 nativo, no se observó actividad GALNS en ninguno de los tiempos de muestreo, mientras que en fibroblastos no afectados se observó una actividad de 13,47 $\pm 1,46 \mathrm{nmol} / \mathrm{mg} / \mathrm{h}$.

Utilizando el vector rAAV-GALNS/24, se lograron los niveles enzimáticos más elevados, con valores de actividad de GALNS hasta de $1,38 \mathrm{nmol} / \mathrm{mg} / \mathrm{h}$ (10\% de los valores en células no afectadas) y $3,05 \mathrm{nmol} / \mathrm{mg} / \mathrm{h}$, en fibroblastos MPS IV A y HEK293, respectivamente (figura 5).

\section{Discusión}

La enfermedad de Morquio A es la mucopolisacaridosis con mayor número de casos reportados en el país $(3,8)$. De hecho, Colombia podría ser el segundo país, después de Brasil, con el mayor número de pacientes afectados por esta enfermedad en Latinoamérica $(2,3)$. A pesar de que la terapia de reemplazo enzimático para la enfermedad de Morquio A comenzará sus ensayos clínicos en el 2008 (http://www.morquio.com), es necesario continuar evaluando otras alternativas que permitan mantener niveles terapéuticos de la enzima por un periodo prolongado y con la que se logre corregir el defecto en la mayor cantidad de tejidos posibles.

En este estudio se evaluó la capacidad de vectores derivados de virus adenoasociados para corregir in vitro la deficiencia de la enzima lisosómica GALNS. Previamente se había construido el vector pIRESneo2-IDS, que porta el ADNc de la enzima lisosómica iduronato-2-sulfato sulfatasa, con el que se logró mantener, durante un mes en fibroblastos MPS II, la expresión de la enzima con valores cercanos al $70 \%$ de la actividad encontrada en células no afectadas (31). Empleando la metodología desarrollada en ese estudio, se construyó el vector de expresión episómica pIRESneo2-GALNS, el cual contiene el ADNc de GALNS bajo el control del promotor e intensificador temprano del citomegalovirus, además de otras secuencias que incrementan la estabilidad del ARNm.

A pesar de que los vectores de tipo AAV no son no patógenos para los humanos, el principal riesgo para su uso es la contaminación con adenovirus durante el proceso de producción (14). Por tal motivo, se seleccionó el método de producción de virus asociados al ADN recombinantes ( $\mathrm{AAAV}$ ) libre de adenovirus desarrollado por X. Xiao et al. (14), en el cual las secuencias que codifican para las proteínas de la cápside (Cap), las que regulan la replicación y empaquetamiento (Rep) y las secuencias adenoviruales necesarias para la producción de virus asociados al ADN, son suministradas en trans por los vectores $\mathrm{pXX2}$ y pXX6, mientras que el casete de expresión, flanqueado por los ITR, es suministrado en un vector derivado de pSUB201. Las secuencias adenovirales restantes son proporcionadas por la línea celular HEK293 (14), razón por la cual esta línea celular fue seleccionada para la producción 
de las partículas virales. El empleo de este sistema permitió obtener rAAV libres de virus ayudadores, sin la necesidad de pasos adicionales para la remoción de estos virus altamente inmunogénicos (32).

Es importante anotar que para el empleo in vivo de estos vectores es necesaria la remoción de contaminantes celulares, principalmente el suero fetal bovino, mediante la realización de gradientes de cloruro de cesio o iodixanol, purificación por cromatografía de afinidad, diálisis y concentración por ultrafiltración $(32,33)$. Sin embargo, los virus producidos en el presente trabajo presentan la suficiente calidad para la realización de los ensayos in vitro.

A pesar de que los vectores derivados de virus asociados al ADN se han empleado en terapia génica desde mediados de los 80 , aún no existe un consenso sobre el método de cuantificación estándar (34). El método ELISA empleado en el presente trabajo para la cuantificación de las partículas virales, presenta la ventaja de no requerir soluciones virales altamente purificadas, como sí lo requieren los métodos basados en PCR en tiempo real, dot-blot o ensayos de infección (34). Sin embargo, la desventaja de este método es que no permite establecer la capacidad de transducción de los virus o el número de partículas con genoma viral. Este último es un aspecto muy importante, pues cuando se realiza la producción de partículas virales recombinantes, sólo un porcentaje de las vectores, generalmente entre el $20 \%$ y $50 \%$, porta el genoma viral (28).

Los títulos virales logrados usando el vector pSUB201 (AAV2 silvestre) de 4,7 × $10^{11}$ cápsides/ $\mathrm{ml}$ fueron equivalentes a los reportados por $X$. Xiao et al. (14) de $6 \times 10^{9}$ unidades de transfección $/ \mathrm{ml}$, las cuales corresponden a 4,7 x1011 cápsides $/ \mathrm{ml}$ (28). Sin embargo, al realizar la corrección por el volumen total de solución viral $(10 \mathrm{ml}$ en este trabajo y $1 \mathrm{ml}$ en $\mathrm{X}$. Xiao et al. (14), se observa un incremento de un orden de magnitud $\left(4,7 \times 10^{12} \mathrm{Vs} .4,7 \times 10^{11}\right.$ cápsides).

Esta diferencia puede ser producto del empleo de liposomas catiónicos durante el proceso de cotransfección, a diferencia del método de fosfato de calcio empleado por otros autores $(13,14,17)$, incrementándose la eficiencia en la entrega del ADN y el número de células transfectadas, y disminuyendo la toxicidad.

Además, el método de fosfato de calcio es bastante sensible en cuanto al $\mathrm{pH}$ de las soluciones, así como a la velocidad de formación y tamaño del precipitado (35). Los títulos virales obtenidos con los vectores recombinantes rAAVGALNS/4, 24 y 39 fueron más bajos que los observados con el virus silvestre, debido a factores como el tamaño del genoma y la ausencia de secuencias adicionales a los ITR que facilitan su producción y empaquetamiento $(36,37)$. Sin embargo, los títulos de los virus recombinantes estuvieron en el rango de $3,98 \times 10^{9}$ a 2,08 $\times 10^{10}$ cápsides $/ \mathrm{ml}$, valores similares a los reportados por X. Xiao et al. (14) al construir rAAV que portan diferentes casetes de expresión.

Los vectores recombinantes producidos en este trabajo fueron del serotipo 2, el cual emplea el proteoglicano heparán sulfato (HSPG) como el receptor necesario para su unión a la membrana celular y el receptor del factor de crecimiento de fibroblastos 1 , la integrina $a_{v} b_{5}$ y el receptor del factor de crecimiento de hepatocitos (HGFR), como los correceptores necesarios para la incorporación del vector (38,39). La HSPG es una molécula ampliamente distribuida en el organismo, por lo que el serotipo 2 tiene la capacidad de infectar una gran variedad de tipos celulares.

En este estudio los vectores rAAV-GALNS se usaron para transfectar células HEK293 y fibroblastos MPS IVA. EI incremento en la actividad de GALNS se pudo detectar desde las primeras 24 horas después de la transfección, alcanzándose a las 48 horas actividades enzimáticas de 3,05 y $1,38 \mathrm{~nm} / \mathrm{mg}$ por hora en células HEK293 y fibroblastos MPS IV A, respectiva-mente, con el vector $\mathrm{rAAV-GALNS/24.}$

Por otro lado, empleando el vector rAAV-GALNS/ 4 a las 48 horas se observó un inexplicable descenso en los valores de la actividad enzimática en fibroblastos, mientras que las células HEK293 se comportaron de una manera similar a lo observado con el vector rAAV-GALNS/24, con un incremento de 3,0 veces de la hora 24 a la 48 versus 2,7 veces en el caso de rAAV-GALNS/24. 
Independientemente del vector utilizado, los valores en células HEK293 son mayores que los logrados en fibroblastos; esto se debe a que las primeras son una línea celular mientras que las otras son producto de un cultivo primario de fibroblastos obtenidos de un paciente con la enfermedad de Morquio A.

Hasta la fecha, el único reporte de transferencia génica para la enfermedad de Morquio A es el de G. Toietta et al. (40) quienes, usando un vector retroviral que porta el ADNc de GALNS bajo el promotor del virus de leucemia de ratón, transfectaron fibroblastos y linfocitos de sangre periférica de individuos normales y pacientes Morquio $A$, así como también queratinocitos humanos, mioblastos de ratón y sinoviocitos de conejo, y lograron incrementos entre 30 y 50 veces en la actividad enzimática con respecto a los valores basales y niveles de GAG iguales 0 menores a los presentes en células normales.

A pesar de que los niveles alcanzados en este estudio son menores que los reportados por $\mathrm{G}$. Toietta et al. (40), algunos resultados indican que, para el manejo de enfermedades lisosómicas, pueden ser suficientes las correcciones cercanas al 10\% para pasar de un fenotipo grave a uno medio (5).

Actualmente se están adelantando ensayos a largo plazo in vitro e in vivo para determinar la capacidad de estos vectores para lograr valores terapéuticos de GALNS. Es importante destacar la ventaja que presentan los vectores de tipo AAV sobre los retrovirales, principalmente, al mantenerse de forma extracromosómica como concatámeros o integrados específicamente, aunque en bajo porcentaje, en el locus AAVS1 del cromosoma 19 (41).

Por su lado, los vectores retrovirales presentan el riesgo de la activación de oncogenes debido a la inserción al azar del vector (34), aunque en la actualidad se adelantan investigaciones tendientes a lograr la integración específica de sitio del vector (42).

Los resultados obtenidos en este estudio constituyen el primer paso hacia el desarrollo de una terapia génica para la enfermedad de Morquio $A$, empleando vectores derivados de virus adenoasociados. Sin embargo, aún se deben evaluar y ajustar otros factores como los promotores, el serotipo del vector y la coexpresión con SUMF1, el cual codifica para la enzima modificadora de formilglicina involucrada en la transformación de cisteína a formilglicina en todas las sulfatasas lisosómicas, y cuya coexpresión con otras sulfatasas ha llevado a notables incrementos de la actividad, tanto in vitro como in vivo $(43,44)$.

\section{Agradecimientos}

Los autores expresan sus agradecimientos a Xiaohuai Zhou del Virus Vector Core Facility de la Universidad de Carolina del Norte en Chapel Hill por su colaboración para la obtención de los plásmidos pSub201, pXX2 y pXX6, y a Adriana Montaño-Suárez de la Universidad de Saint Louis por su colaboración en la corrección y análisis.

\section{Conflicto de intereses}

Los autores declaran que no existe conflicto de intereses.

\section{Financiación}

Este trabajo se realizó con el apoyo de Colciencias proyecto No. 1203-04-246-99, la Fundación para la Promoción de la Ciencia y la Tecnología del Banco de la República, proyecto № 974, y la Pontificia Universidad Javeriana, sede Bogotá.

\section{Referencias}

1. Neufeld E, Muenzer J. The mucopolysaccharidosis. En: Scriver C, Beaudet A, Sly W, Valle D, editores. The metabolic and molecular bases of inherited diseases. New York: McGraw-Hill; 2001. p. 3421-52.

2. Montaño AM, Tomatsu S, Gottesman G, Smith M, Orii T. International Morquio A registry: Clinical manifestation and natural course of Morquio A disease. J Inherit Metab Dis. 2007;30:165-74.

3. Tomatsu S, Montaño A, Nishioka T, Gutiérrez M, Peña 0 , Trandafirescu G, et al. Mutation and polymorphism spectrum of the GALNS gene in mucopolysaccharidosis IVA (Morquio A). Hum Mutat. 2005;26:500-12.

4. Northover H, Cowie RA, Wraith JE. Mucopolysaccharidosis type IVA (Morquio syndrome): a clinical review. J Inherit Metab Dis. 1996;19:357-65.

5. Cheng SH, Smith AE. Gene therapy progress and prospects: gene therapy of lysosomal storage disorders. Gene Ther. 2003;10:1275-81. 
6. Tomatsu S, Fukuda M, Masue K, Sukegawa T, Fukao A, Yamagishi $\mathrm{T}$, et al. Morquio disease: isolation, characterization and expression of full-length cDNA for human $\mathrm{N}$-acetylgalactosamine-6-sulfate sulfatase. Biochem Biophys Res Commun. 1991;181:677-83.

7. Cooper D, Ball E, Stenson P, Phillips A, Howells K, Mort M. The Human Gene Mutation Data Base at the Institute of Medical Genetics in Cardiff. [Consultado: los autores deben colocar la fecha de consulta]. Disponible en: http://www.hgmd.cf.ac.uk.

8. Kato Z, Fukuda S, Tomatsu S, Vega H, Yasunaga T, Yamahishi A, et al. A Novel Common Missense Mutation G301C in the N-Acetylgalactosamine-6-sulfate Sulfatase Gene in Mucopolysaccharidosis IVA. Hum Genet. 1997;101:97-101.

9. Bernal J, Briceño I. Genetic and other diseases in the pottery of Tumaco-La Tolita culture in ColombiaEcuador. Clin Genet. 2006;70:188-91.

10. Herzog RW, Hagstrom JN, Kung SH, Tai SJ, Wilson JM, Fisher KJ, et al. Stable gene transfer and expression of human blood coagulation factor IX after intramuscular injection of recombinant adenoassociated virus. Proc Natl Acad Sci U S A. 1997;94:5804-9.

11. Snyder RO, Miao CH, Patijn GA, Spratt SK, Danos $\mathbf{O}$, Nagy $\mathrm{D}$, et al. Persistent and therapeutic concentrations of human factor IX in mice after hepatic gene transfer of recombinant AAV vectors. Nat Genet. 1997;16:270-6.

12. Rutledge EA, Russell DW. Adeno-associated virus vector integration junctions. J Virol. 1997;71:8429-36.

13. Xiao W, Berta SC, Lu MM, Moscioni AD, Tazelaar J, Wilson JM. Adeno-associated virus as a vector for liver-directed gene therapy. J Virol. 1998;72:10222-6.

14. Xiao X, Li J, Samulski R. Production of high-titer recombinant adeno-associated virus vectors in the absence of helper adenovirus. J Virol. 1998;72:2224-32.

15. Fisher KJ, Kelley WM, Burda JF, Wilson JM. A novel adenovirus-adeno-associated virus hybrid vector that displays efficient rescue and delivery of the AAV genome. Hum Gene Ther. 1996;7:2079-87.

16. Vincent KA, Piraino ST, Wadsworth SC. Analysis of recombinant adeno-associated virus packaging and requirements for rep and cap gene products. J Virol. 1997;71:1897-905.

17. Samulski RJ, Chang LS, Shenk T. Helper-free stocks of recombinant adeno-associated viruses: normal integration does not require viral gene expression. J Virol. 1989;63:3822-8.

18. Sands M, Davidson B. Gene therapy for lysosomal storage diseases. Mol Ther. 2006;13:839-49.

19. Daly TM, Vogler C, Levy B, Haskins ME, Sands MS. Neonatal gene transfer leads to widespread correction of pathology in a murine model of lysosomal storage disease. Proc Natl Acad Sci USA. 1999;96:2296-300.

20. McEachern K, Nietupski J, Chuang W, Armentano $\mathrm{D}$, Johnson J, Hutto $\mathrm{E}$, et al. AAV8-mediated expression of glucocerebrosidase ameliorates the storage pathology in the visceral organs of a mouse model of Gaucher disease. J Gene Med. 2006;8:719-29.

21. Daly TM, Ohlemiller KK, Roberts MS, Vogler CA, Sands MS. Prevention of systemic clinical disease in MPS VII mice following AAV-mediated neonatal gene transfer. Gene Ther. 2001;8:1291-8.

22. Fraites TJ Jr, Schleissing MR, Shanely RA, Walter GA, Cloutier DA, Zolotukhin I, et al. Correction of the enzymatic and functional deficits in a model of Pompe disease using adeno-associated virus vectors. Mol Ther. 2002;5:571-8.

23. Park J, Murray GJ, Limaye A, Quirk JM, Gelderman MP, Brady RO, et al. Long-term correction of globotriaosylceramide storage in Fabry mice by recombinant adeno-associated virus-mediated gene transfer. Proc Natl Acad Sci USA. 2003;100:3450-4.

24. Hennig AK, Ogilvie JM, Ohlemiller KK, Timmers AM, Hauswirth WW, Sands MS. AAV-mediated intravitreal gene therapy reduces lysosomal storage in the retinal pigmented epithelium and improves retinal function in adult MPS VII mice. Mol Ther. 2004;10:106116.

25. Daly TM, Okuyama T, Vogler C, Haskins ME, Muzyczka N, Sands MS. Neonatal intramuscular injection with recombinant adeno-associated virus results in prolonged beta-glucuronidase expression in situ and correction of liver pathology inmucopolysaccharidosis type VII mice. Hum Gene Ther. 1999;10: 85-94.

26. Ponder K, Haskins M. Gene therapy for mucopolysaccharidosis. Expert Opin Biol Ther. 2007;7: 1333-45.

27. Miwa K, Matsui K, Terabe M, Ito K, Ishida M, Takagi $\mathrm{H}$, et al. Construction of novel shuttle vectors and a cosmid vector for the glutamic acid-producing bacteria Brevibacterium lactofermentum and Corynebacterium glutamicum. Gene. 1985;39:281-6.

28. Grimm D, Kern A, Pawlita M, Ferrari F, Samulski R, Kleinschmidt1 J. Titration of AAV-2 particles via a novel capsid ELISA: packaging of genomes can limit production of recombinant AAV-2. Gene Ther. 1999; 6:1322-30

29. Russell DW, Alexander IE, Miller AD. DNA synthesis and topoisomerase inhibitors increase transduction by adeno-associated virus vectors. Proc Natl Acad Sci USA. 1995;92:5719-23.

30. vanDiggelen $\mathbf{O}$, Zhao $H$, Kleijer $\mathbf{W}$, Janse $H$, Poorthuis B, Pelt JV, et al. A fluorometric enzyme assay for the diagnosis of Morquio type A. Clin Chem Acta. 1990;187:131-40. 
31. Barrera L, Gutierrez M, Ceron F, Garcia L. Evaluation of an episomal expression construct containing the cDNA of iduronate sulfatase in (IDS) in fibroblasts from a patient with hunter syndrome. J Inherit Metab Dis. 2002;25(Suppl.1):160.

32. Zolotukhin S. Production of recombinant adenoassociated virus vectors. Hum Gene Ther. 2005; 16: 551-7.

33. Zolotukhin S, Byrne B, Mason E, Zolotukhin I, Potter $\mathrm{M}$, Chesnut $\mathrm{K}$, et al. Recombinant adeno-associated virus purification using novel methods improves infectious titer and yield. Gene Ther. 1999;6:973-85.

34. Aucoin MG, Perrier M, Kamen AA. Critical assessment of current adeno-associated viral vector production and quantification methods. Biotechnol Adv. 2008;26:73-88.

35. Okoyama H, Chen C. Calcium phosphate mediated gene transfer into established cell lines. En: Murray EJ, editor. Methods in molecular biology: Gene transfer and expression protocols. Clifton: The Humana Press; 1991. p. 15-20.

36. Lu Y. Recombinant adeno-associated virus as delivery vector for gene therapy-a review. Stem Cells Dev. 2004;13:133-45.

37. Ward $\mathbf{P}$, Clément $\mathbf{N}$, Linden $\mathbf{M}$. cis effects in adenoassociated virus type 2 replication. J Virol. 2007;81: 9976-89.
38. Summerford C, Samulski RJ. Membrane-associated heparan sulfate proteoglycan is a receptor for adenoassociated virus type 2 virions. J Virol. 1998;72:1438-45.

39. Wu Z, Asokan A, Samulski R. Adeno-associated virus srotypes: vector toolkit for human gene therapy. Mol Ther. 2006;14:316-27.

40. Toietta G, Severini G, Traversari C, Tomatsu S Sukegawa K, Fukuda S, et al. Various cells retrovirally transduced with $\mathrm{N}$-acetylgalactosoamine-6-sulfate sulfatase correct Morquio skin fibroblasts in vitro. Hum Gene Ther. 2001;12:2007-16.

41. Hacein-Bey-Abina S, von Kalle C, Schmidt M, Le Deist $\mathrm{F}$, Wulffraat $\mathrm{N}$, McIntyre $\mathrm{E}$, et al. A serious adverse event after successful gene therapy for Xlinked severe combined immunodeficiency. $N$ Engl J Med. 2003;348:255-6.

42. Lewinski MK, Bushman FD. Retroviral DNA integration-mechanism and consequences. Adv Genet. 2005;55:147-81.

43. Landgrebe J, Dierks T, Schamidt B, Figura Kv. The human SUMF1 gene, required for posttranslational sulfatase modification, defines a new gene family which is conserved from pro- to eukaryotes. Gene. 2003;316:47-56.

44. Cosma M, Pepe P, Annunziata I, Newbold R, Grompe M, Parenti G, et al. The multiple sulfatase deficiency gene encodes an essential and limiting factor for the activity of sulfatases. Cell. 2003;113:445-56. 